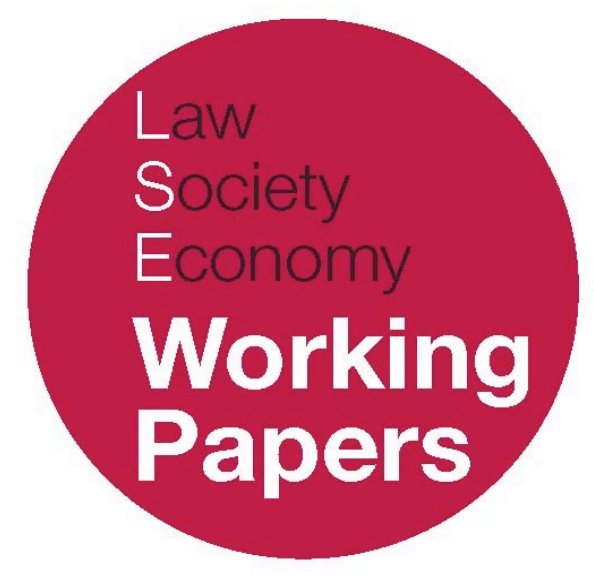

\title{
Beyond History and Boundaries: Rethinking the Past in the Present of International Economic Law
}

\author{
Rafael Lima Sakr \\ LSE Law, Society and Economy Working Papers 9/2018 \\ London School of Economics and Political Science \\ Law Department
}

\begin{abstract}
This paper can be downloaded without charge from LSE Law, Society and Economy Working Papers at: www.lse.ac.uk/collections/law/wps/wps.htm and the Social Sciences Research Network electronic library at: http://ssrn.com/abstract $=3194660$

CRafael Lima Sakr. Users may download and/or print one copy to facilitate their private study or for non-commercial research. Users may not engage in further distribution of this material or use it for any profit-making activities or any other form of commercial gain.
\end{abstract}




\title{
Beyond History and Boundaries: Rethinking the Past in the Present of International Economic Law
}

\author{
Rafael Lima Sakr
}

\begin{abstract}
History and boundaries are the foundations of international economic law (IEL) as a professional and intellectual field. History is often told to support a wide variety of present projects, norms and ideas by appealing to the past. Boundary is a technique frequently used to map and defend an exclusive domain for applying the IEL expertise to a broad range of programmes, rules and theories. This article first describes how history and boundaries interact to produce a 'traditional' view of IEL's past and present place in the world economy. This interaction plays a central role in structuring how international lawyers assert the authority and legitimacy of IEL in global economic governance. It then argues that the commitments of the traditional approach to Anglocentrism and Modernism limit lawyers' ability to understand and solve the present-day issues, since it produces lessons only in support of the dominant programmes, norms and ideas under contestation. Consequently, it constrains, instead of empowers, lawyers' imagination. Building on this critique, the article outlines an alternative approach devised to rethink the IEL field and, more importantly, which past or new projects, norms and theories do or do not count (or should or should not count) as part of it. It concludes with reflections on how we might go about reimagining IEL in response to the contemporary challenges to global economic governance.
\end{abstract}

\footnotetext{
* Ph.D. Candidate at the London School of Economics and Political Science. For conversations, comments, and critique on earlier drafts, I am grateful to Andrew Lang, Jan Kleinheisterkamp, Martin Clark, Dagmar Myslinska, Aaron Wu and Mackenzie Common. Errors are mine alone. I am thankful to the Society of International Economic Law, the JEIL Editors and the Oxford University of Press for awarding the original manuscript of this paper the 2017-2018 SIEL/JIEL/OUP Essay Prize.
} 


\section{I.INTRODUCTION}

The field of international economic law (IEL) holds in high esteem its own history and boundaries. From its founding fathers to today's highly specialised lawyers, debates about the origins and evolution, autonomy and frontiers of IEL have been an essential part of the discipline. Yet, both - history and boundaries - seem to be experienced as unrelated, or perhaps contrasting, modes of disciplinary governance situated on opposite sides of the IEL expertise.

On the one hand, history tends to trigger lawyers' imagination of IEL as a disciplinary technique that governs the movement of meanings across time. Historical narratives are regarded as a way of providing support to a wide variety of IEL projects, norms, institutions, theories and methods by connecting their past to the present. On the other hand, boundaries tend to cause lawyers to think of IEL as a disciplinary technique that controls the movement of meanings across space. Demarcation is considered a way to vindicate the existence of $a(n)$ (exclusive) domain for the application of IEL expertise to a broad range of programmes, rules, regimes, theories and methods, by distinguishing it from the others.

The purpose of this article is to describe, criticise and offer an alternative to the disciplinary consensus around the interaction between the history and boundaries of international economic law. By examining this interplay, I intend to rethink the ways in which lawyers have approached and dealt with foundational and present-day questions about global economic law and governance. More specifically, I question what a study of the history and boundaries can tell us today about the current limitations of IEL expertise and the possibilities it provides to reform or transform itself and the contemporary international economic order. Hence, my ultimate goal is to invite the IEL field to reflect upon the self-imposed disciplinary restraints and their political and intellectual consequences.

The argument unfolds in three parts. Section II presents and analyses the traditional approach to the history of international economic law. It focuses particularly on the ways in which lessons are drawn from this history in order to inform legal expertise. Section III discusses the limits of the traditional approach by suggesting that the conventional commitment to Modernism and Anglocentrism tends to obfuscate the instrumentalisation of past events to support or exclude present projects, rules, regimes, theories and techniques. The ultimate consequence is to adversely affect lawyers' ability to respond to the current problems faced by global economic governance. Building on this critique, section IV proposes to rethink how history and boundaries relate to one another by offering an alternative approach. The aspiration is to empower international lawyers with ways to reimagine the IEL field and, more importantly, reconsider 
which past or present projects, norms and theories do or do not count (or should or should not count) as part of it.

In the Conclusion, the article returns to the central issues involving the interplay between history and boundaries inside and outside of the field of international economic law. From an external viewpoint, it argues that the disciplinary boundaries have done a great deal of work in preventing international lawyers from offering satisfactory solutions to the contemporary challenges facing global economic governance. From an internal perspective, it asserts that the field's boundaries result from the interaction between intellectual debates meaningfully grounded in history lessons and the political disputes arising out of collective and individual pursuits of authority and legitimacy. Therefore, to break up the imaginative gridlock on the IEL expertise, the solution advocated by the article is to move away from the traditional approach and towards to the alternative approach.

\section{FROM THE PRESENT TO THE PAST, THE TRADITIONAL APPROACH TO THE HISTORY OF INTERNATIONAL ECONOMIC LAW}

The purpose of this section is to depict the traditional approach to the history of international economic law from the scholarly literature. The analysis suggests that the traditional approach is widely employed to construct history lessons, which, in turn, play a fundamental role in influencing the ways lawyers understand and offer solutions to the contemporary challenges of global economic governance.

\section{Robert Howse and the Present Boundaries of International ECONOMIC LAW}

In a recent publication, the Canadian professor Robert Howse ${ }^{1}$ invites us international lawyers - to rethink the boundaries of the field of international economic law. ${ }^{2}$ He calls our attention to the fact that only a few of us possess appropriate knowledge of economics to reflect upon and deal with the contemporary problems of global economic governance. ${ }^{3}$ He has in mind our limitations when coping with the political, social and economic consequences

\footnotetext{
${ }^{1}$ Robert Howse is a Canada-born law professor at the New York University School of Law, located in the United States.

${ }^{2}$ For an overview of the legal field as a professional and intellectual arena structured and organized by shared core features, see Pierre Bourdieu, The Force of Law: Toward a Sociology of the Juridical Field, 38 HASTINGS L.J. 805 (Richard Terdiman trans., 1987). For the application of Bourdieu's view to international trade law field, see Andrew Lang, WORLD TRADE LAW AFTER NEOLIBERALISM: Reimagining the Global ECONOMIC ORDER 186-188 (2011).

3 See Robert Howse, Economics for Progressive International Lawyers: a Review Essay, 5 LONDON REVIEW OF INTERNATIONAL LAW 187-196 (2017).
} 
arising out of the unequal distribution of the gains and losses of the last three decades of globalisation. It seems that his concern lies, particularly, in the apparent mismatch between the powerful position held by international lawyers in the world economy and our lack of satisfactory understanding of economics, or perhaps uncritical acceptance of dominant economic doctrines as valid and legitimate. To understand the ways in which international lawyers have been implicated in managing the present-day international economic order, as well as in shaping the conditions of possibility for transforming it, he offers a brief account of his own experience as a junior scholar in North America to illustrate how law students have trained in the IEL expertise since the late-1980s.

In his recollection, Howse describes the steps undertaken by him to accede to the IEL field. ${ }^{4}$ At university, he was initiated into the characteristic ways of thinking of and arguing about IEL rules, institutions and doctrines. A combination of historical, theoretical and doctrinal lessons taught him, implicitly, where, why and how the field's boundary was established and sustained. Following a long jurisprudential tradition across Western countries, the disciplinary line was drawn by attributing an ontological definition to IEL, which would carry with it implicit normative consequences. International economic law, recalls Howse, has been taught as "an instrument that serves rational international economic policy; rational policy is about efficiency; efficiency leads to growth; efficiency requires open markets, with strong protections for property and contractual rights and disciplines on government intervention. Questions of justice or redistribution should remain 'elsewhere': they do not belong to international economic law." 5

To my mind, Howse's recollection calls attention, consciously or otherwise, to the effects of a fundamental, but often neglected, mode of expert governance ${ }^{6}$ employed by the IEL field, disciplinary boundary. ${ }^{7}$ The notion of boundaries tends to cause lawyers to think of IEL as a technique ${ }^{8}$ for controlling the movement of

\footnotetext{
${ }^{4}$ Howse, above n 3 , at $188-189$.

${ }^{5}$ Howse, above $\mathrm{n} 3$, at 188.

${ }^{6}$ Inspired by science and technology studies (STS) literature, modes of expert governance are conceived as disciplinary mechanisms for the production, management and application of knowledge, norms and identities. They are created and used to coordinate expert systems and purposive action. In this sense, they are relatively institutionalised structures of governing decision-making constituted by a characteristic range of substantive and procedural assumptions as well as styles of thinking and reasoning. Consequently, they are employed to make, sustain and transform knowledge, norms and identities with the purpose of applying them to frame the issues under consideration and craft arguments in order to influence concrete situations or to prevent and resolve disputes. The political and intellectual process through which knowledge, norms and identities are constituted and adapted is defined as governance. For a STS overview of expert governance, see generally Alan Irwin, STS Perspectives on Scientific Governance, in THE HANDBOOK OF SCIENCE AND TECHNOLOGy STUDies (Edward J. Hackett $e t$ al (eds.), 2008).

${ }^{7}$ For an overview of disciplinary demarcation and professional boundary, see generally Michel Callon, Introduction: the embeddedness of markets in economics, 46 THE SOCIOLOGICAL REVIEW 1-57 (1998); Sida Liu, The Legal Profession as a Social Process: A Theory on Lawyers and Globalization, 38 LAW \& SOCIAL INQUiRY 676677 (2013).

8 Technique is conceived as a characteristic style of organising material, procedural and aesthetical features into formal methods, skills and routines that produce outcomes associated with universality, durability, stability, scientific objectivity and political neutrality. Legal technologies tend to include some
} 
meanings across space through demarcation. It is implicated directly in controlling what and who count or not as part of IEL, and, indirectly, in determining which rules, actors and knowledge are authoritative and legitimate. Within the IEL field, demarcation is a process involving decision-making and consensus-building. The consensus around the authority and legitimacy of norms, actors and ideas is built up by a discipline's ritualised process of framing and answering questions. ${ }^{9}$ The responses are choices about intellectual, normative and political matters. They may take the form of a project, theory, method or argument. If successful in achieving internal consensus, these responses are likely to produce powerful spatial effects over legal expertise and might be used to affect global policymaking. They, therefore, serve not only to establish and sustain the IEL frontiers today but also to structure the ways in which lawyers understand and respond to the problems arising from the world economy.

Moreover, disciplinary demarcation is sensitive to political and intellectual dynamics of expert differentiation. Boundaries are shaped by the continuous professional practices and intellectual debates of international lawyers located inside and outside ${ }^{10}$ the IEL field. In this context of global economic governance, boundary-drawing is a process of relational contestation undertaken by distinct professions engaged in influencing policy-and law-making. Demarcation is, in this sense, a disciplinary technique employed to vindicate the existence of a(n) (exclusive) domain for the application of IEL expertise to a broad range of programmes, rules, regimes, ideas and methods. Therefore, the boundaries of international economic law are continuously restated by lawyers as another strategy of reaffirming the field's identity, mission and influence in global economic governance.

Rethinking Howse's narrative through the lens of disciplinary boundaries opens the possibility of retelling his own recollection from a distinct angle. As I shall discuss below, ${ }^{11}$ some lawyers, situated predominantly in North America in the late 1970s, proposed to use a combination of theories and methods grounded in legal realism, functionalism and pragmatism, to reimagine the international law

\footnotetext{
of the following elements: "(1) certain ideologies - legal instrumentalism and managerialism [...] (2) certain categories of experts - especially scholars, bureaucrats and practitioners who treat the law as a kind of tool or machine and who see themselves as modest but expertly devoted technicians; (3) a problem-solving paradigm - an orientation toward defining concrete, practical problems and toward crafting solutions; (4) a form of reasoning and argumentation, from eight-part tests to reasoning by analogy, to the production of stock types of policy arguments to practices of statutory interpretation or citation to case law" (Annelise Riles, COLLATERAL KNOWLEDGE: LEGAL REASONING IN THE GLOBAL FINANCIAL MARKETS (2011)).

${ }_{9}$ Disciplinary questions with powerful demarcation effects are: what is international economic law? What are the sources of IEL? What are the interpretative methods? How does IEL relate to other provinces of (public/private; domestic/regional/international) law and to other domains of international economic policymaking (e.g. economics, international relations, political and social sciences). Who has competence/jurisdiction/expertise over the matter?

${ }^{10}$ For instance, foreign affairs and trade ministries, law schools and firms, non-governmental organisations, domestic and international courts and institutions for economic affairs.

11 See generally below n 46-49, and accompanying text.
} 
of world economy as a distinct, specialised domain of expertise. They offered a new conceptual definition ${ }^{12}$ and employed it to rework a set of legal norms and ideas in order to support and universalise programmes for international economic law and governance. This involved demarcating the authority of their expertise inside and outside of the legal domain. ${ }^{13}$

Externally, they employed IEL expertise to claim ultimate competence over legal rules, institutions and doctrines that constituted and regulated the international economic order. This mainly involved disciplinary disputes with other international economic policymakers to exert legitimate authority over the international laws of the World Bank, the International Monetary Fund (IMF), the General Agreement on Tariffs and Trade (GATT) and international investment agreements (IIAs). Internally, historical narratives were amalgamated with legal and economic theories so as to assert the existence of a special body of positive norms and regimes, which required a specialised set of knowledge and skills distinct from other (public/private and international/domestic) law provinces. These unique characteristics led to the gradual formation of a distinguished intellectual and professional field, holding a specific identity and mission. This view of international economic law was chiefly developed in the late 1980s in the Anglo-American context. It quickly spread out after the end of the Cold War and the rise of the United States as the economic hegemon. By the early 2000s, when I was initiated in the IEL field, what today can be called the 'Anglo-American vision' had already become the orthodoxy as much as in the Bretton Woods institutions, the Bank for International Settlement (BIS), the World Trade Organisation (WTO), the International Centre for Settlement of Investment Disputes (ICSID) as in Brazilian law schools and firms, companies and government.

What this brief reinterpretation of Howse's account seems to suggest is that drawing boundaries has less to do with finding the field's normative, economic or natural foundations. Rather, it appears to be more related to strategic positions taken by historically situated lawyers who intended not only to exercise influence by claiming exclusive expertise over certain institutional and jurisprudential domains but also to engage in the realisation of specific projects for global economic governance. These decisions are not made in the abstract. They often involve pledging their commitment to intellectual traditions and affiliating to professional groups, and so affected by the preoccupations, moral values and

\footnotetext{
12 Already described by Howse (see above n 5, and accompanying text).

${ }^{13}$ Robert Howse, From Politics to Technocracy-and Back Again: The Fate of the Multilateral Trading Regime, 96 The American Journal of International Law 98-99 (2002). See also David Kennedy, The International Style in Postwar Law and Policy, 1 Utah L. Rev. 7-103 (1994); Arie Reich, From Diplomacy to Law: The Juridicization of International Trade Relations, 17 Nw. J. INT’L L. \& BUS. 775-776 (1996-1997); Joseph H.H. Weiler, The Rule of Lanyers and the Ethos of Diplomats, 35 JOURNAL OF WORLD Trade 194-197 (2001).
} 
interests of national elites, transnational experts and, of course, legal communities. ${ }^{14}$

Three such choices seem particularly important to reflect upon since they are at the core of the IEL field's identity/mission, and so might be useful as steppingstones to find responses to the current issues facing global economic governance. First, by ascribing a definition to international economic law, ideas and practices are ex ante framed in and out of the IEL expertise. Second, by qualifying particular methods as authoritative to identify which norms and regimes are part of IEL, a set of techniques is included while the rest is dismissed as non-IEL for being unable to entail valid and authoritative responses. Finally, by agreeing on a programme, alternatives are marginalised and perhaps turn into either ideological rivals or expert competitors to the IEL field itself.

In the Anglo-American environment where Howse is situated, the majority of international lawyers have regarded themselves as liberal, cosmopolitan experts who, alongside other specialists and policymakers, are committed to promoting the rise of living standards through the application of scientific knowledge and techniques to rules and institutions of global economic governance, but whose efforts have been historically slowed down by political, ideological or economic forces. As emphasised by Howse, the acceptance of IEL as a neutral instrument devised for promoting and sustaining - what has been called - a Neoliberal programme ${ }^{15}$ for global economic governance, through a particular set of international and domestic rules, institutions and doctrines, singles out a much wider constellation of potentially applicable legal ideas, practices, projects and norms. ${ }^{16}$ The unproblematic understanding and the commitment of contemporary lawyers to Neoliberalism often marginalise relevant questions related to social justice and economic redistribution by setting humans rights and development policies outside the field's domain. ${ }^{17}$

This conventional understanding - dominant since the 1980s - has recently lost its external appeal. ${ }^{18}$ The succession of political, social and economic crises of

\footnotetext{
14 David Kennedy, The Twentieth Century Discipline of International Law in the United States, in LOOKING BACK AT LAW'S CENTURY 409-414 (Austin Sarat et al. eds., 2002).

${ }^{15}$ For the definition of Neoliberalism, see below $\mathrm{n} 91$, and accompanying text.

16 Howse, above n 3, at 188-189, and accompanying text.

17 Howse, above n 3, at 188-189. See also Robert Howse, The World Trade Organization 20 Years On: Global Governance by Judiciary, 27 EuROPEAN JOURNAL OF INTERNATIONAL LAW 9-77 (2016).

18 See generally Timothy Meyer, Saving the Political Consensus in Favor of Free Trade, 70 VAND. L. REv. 9851026 (2017). See also Michael Spence, Donald Trump and the New Economic Order (2006), https://www.project-syndicate.org/commentary/nationalist-approach-to-economic-policy-by-michaelspence-2016-11; Anatole Kaletsky, The Crisis of Market Fundamentalism (2016), https:/ /www.projectsyndicate.org/commentary/populist-revolt-crisis-of-capitalism-by-anatole-kaletsky-2016-12; Kemal Derviş, The Win-Win Fantasy of Liberal Democracy (2017), https://www.projectsyndicate.org/commentary/failure-to-predict-brexit-and-trump-by-kemal-dervis-2016-12; Michael J. Sandel, Lessons from the populist revolt (2017), https:/ / www.project-syndicate.org/onpoint/lessons-fromthe-populist-revolt-by-michael-sandel-2017-01?barrier=accesspay; Rohinton Medhora, The Future of Trade (2017), https://www.project-syndicate.org/onpoint/the-future-of-trade-by-rohinton-p--medhora-201706?barrier=accesspay; Helmut K. Anheier, Rage Against the Elites (2017), https://www.projectsyndicate.org/onpoint/rage-against-the-elites-by-helmut-k--anheier-2017-10?barrier=accesspay; Paola
} 
the early $21^{\text {st }}$ century has caused people across jurisdictions to either distrust or challenge the widespread consensus around the benefits of the Neoliberal style of governing the world economy. This entailed a challenge to the legitimacy and authority of international economic regimes and organisations, on the one hand, and policymaking experts (generally) and lawyers (particularly), on the other. The 2000-2002 Dot-com bubble, the 2001 Turkish crisis, the 2007-2009 global financial crisis, the 2010-2012 European sovereign debt crisis, the 2014 Russian crisis and the 2014-2017 Brazilian crisis are perceived as having exposed the vulnerabilities of global economic law and governance. They also have unveiled that the international management of economic globalisation and its crises, through expert application and interpretation of IEL rules and institutions, has impacted countries and individuals in uneven ways.

Additionally, the lack of effective or satisfactory responses by political and expert elites have increased popular dissatisfaction. ${ }^{19}$ Many people in developed countries discovered what their peers in the developing world had figured out a long time ago: globalisation produces structural imbalances between winners and losers. Using their privileged position, these individuals, who believed they were left behind, expressed their frustration by attacking important pillars of the international economic order. The years of 2016-2017 have witnessed two more significant and effective assaults in the Anglo-American context: Brexit and Trump's election. ${ }^{20}$

\section{Steve Charnovitz and the Present History of International ECONOMIC LAW}

At present-day, The Field of International Economic Law by the American professor Steve Charnovitz ${ }^{21}$ symbolises the disciplinary consensus around the

Subacchi, Economic Crises and the Crisis of Economics (2017), https://www.project-

syndicate.org/commentary/economists-should-restore-lost-credibility-by-paola-subacchi-2017-01; Richard Baldwin, Trump's Anachronistic Trade Strategy (2017), https://www.projectsyndicate.org/commentary/trump-trade-policy-tariffs-by-richard-baldwin-2017-02; Dani Rodrik, Too Late to Compensate Free Trade's Losers (2017), https://www.project-syndicate.org/commentary/freetrade-losers-compensation-too-late-by-dani-rodrik-2017-04; Dani Rodrik, Straight Talk on Trade (2017), https://www.project-syndicate.org/commentary/trump-win-economists-responsible-by-dani-rodrik2016-11; Dani Rodrik, Too Late to Compensate Free Trade's Losers (2017), https://www.projectsyndicate.org/commentary/free-trade-losers-compensation-too-late-by-dani-rodrik-2017-04.

19 See generally Anthea Roberts, Being Charged by an Elephant: A story of globalization and inequality (2017), https://www.ejiltalk.org/being-charged-by-an-elephant-a-story-of-globalization-and-inequality/; Kaushik Basu, Inequality in the Twenty-First Century (2017), https://www.project-

syndicate.org/commentary/profit-sharing-basic-income-by-kaushik-basu-2017-12.

20 The British citizens voted in the 2016 referendum to take the United Kingdom out of the European Union. Trump campaigned and now has sought to implement America First, a nationalist and protectionist policy that has led the United States to withdraw from the Trans-Pacific Partnership Agreement, to pull Canada and Mexico into renegotiations of the North American Free Trade Agreement, and to threaten to dismantle or exit from the WTO.

${ }^{21}$ Steve Charnovitz is a US-born law professor at the George Washington University Law School, located in the United States. 
history of international law of the world economy.22 Section I starts off by providing a brief introduction to the most-acceptable views on the two-core ontological (what is IEL?) and epistemological (how is IEL identified?) questions underlying the field and by pointing out that both are still unsettled. Then, Charnovitz attempts to offer his own concept by merging the very broad meanings of "international + economic + law" with a functionalist method. ${ }^{23}$ " A [international] law of the world economy could possibly apply to three phenomena: (i) rules as between states, (ii) rules for how states treat individuals, and (iii) rules for individual to individual transactions." 24 However, he notices that "[that definition is] perhaps too broad. Consequently a reconsideration of method may be required." 25 To deal with the over-inclusiveness, Charnovitz uses legal functionalism to acknowledge tactically the existence of "specialized bodies of public international law without necessarily classifying them as part of [IEL]." 26 The result seems not to be satisfactory since he falls back to considerations about the complexities in determining the nature of IEL. To move forward, Charnovitz turns strategically to history in order to find in the past evidence to fill his abstract concept of IEL with concreteness.

\section{A. The Institutional History of International Economic Law}

In Section II, the history of the IEL field is chronicled as a series of progressive moments that tie economic crises to institutional responses and legal justifications. ${ }^{27}$ Very similar to other conventional accounts ${ }^{28}$, Charnovitz provides a timeline of the IEL evolution, indicating the existence of legal rules and institutions that were used from the golden age of British-led free trade to the interwar period, and then to the post-war international economic order. He also

\footnotetext{
22 See generally Steve Charnovitz, The Field of International Economic Law, 17 J. INT’L. ECON. L. 607-626 (2014). For like-minded conventional narratives about the history of international economic law, see generally the widely accepted works of Gerhard Loibl, International Economic Law, in INTERNATIONAL LAW (Malcolm Evans, ed., 2003); Aust Anthony, HANDBOOK OF INTERNATIONAL LAw (2005); Asif H. Qureshi and Andreas R. Ziegler, InTERnATIONAL ECONOMiC LAw (2007); Andreas F. Lowenfeld,

INTERNATIONAL ECONOMIC LAW (2008); Ernst-Ulrich Petersmann, INTERNATIONAL ECONOMIC LAW IN THE 21St Century: Constitutional Pluralism And Multilevel GovernanCE of InTERdePendent Public Goods (2012); and Matthias Herdegen, PrinciPles of International ECONOMIC LAW (2016).

23 "A [international] law of the world economy could possibly apply to three phenomena: (i) rules as between states, (ii) rules for how states treat individuals, and (iii) rules for individual to individual transactions" (Charnovitz, above n 22, at 607-611).

24 Ibid, at 610.

25 Ibid, at 610

26 Ibid, at 611

27 Ibid, at 611-616.

28 See generally Loibl, above n 22; Aust, above n 22; Qureshi and Ziegler, above n 22; Lowenfeld, above $n$ 22; John H. Jackson, Part I: The state of international economic law - 2005, 8 J. INT'L ECON. L. 3-15 (2005); John H. Jackson, International Economic Law: Complexities and Puzzles, 10 J. Int'l Econ. L. 3-12 (2007); Gilbert R. Winham, The Evolution of the World Trading System - The Economic and Policy Context, in THE Oxford Handbook of International Trade LAw (Daniel Bethlehem ed., 2009); Michael J. Trebilcock et al, The Regulation of International Trade (2012); Petersmann, above n 22; and Herdegen, above n 22.
} 
chooses, as many others, to emphasise the international regulation of trade affairs due to their exceptional importance to the IEL history. ${ }^{29}$

The conventional narrative tells that from the late 19th century until 1914 the world trade was governed by the so-called Liberal international economic regime centred on the classical principle of freedom of commerce. ${ }^{30}$ The outbreak of World War I massively disrupted the international trading system of bilateral and preferential arrangements rudimentarily tied by MFN clauses. The peace did not repair the fractions. Rather, the 1919 Versailles Treaty contributed to produce long-term, deleterious impacts on Germany's economy, pushing it to adopt a predatory economic strategy. This contributed partially to a general surge in beggar-thy-neighbour measures throughout the 1920s. In this context, the MFN clause fell into disuse encouraging countries to enter into bilateral arrangements.

The international trading system was already severely cracked by the end of the 1920s when the Great Depression caused the downfall of many domestic economies. ${ }^{31}$ To preserve national production and employment, extreme forms of discriminatory and protectionist measures were adopted. The Smoot-Hawley Tariff Act enacted by the United States in 1930 was the most notorious for quickly provoking comparable retaliatory reactions by its major trading partners. ${ }^{32}$ All these predatory policies not only exacerbated the effects of the Great Depression but also led the international trade regime to an institutional paralysis. When the 1934 Reciprocal Trade Agreements Act was passed by the US Congress the time for peaceful free trade policies was gone. The outbreak of World War II cemented the end of the Liberal international economic order.

The combination of the Franco-German economic revanchism, generalised trade wars and the Great Depression, with an ineffective Liberal trading system and marginal classical international law, served as history lessons for what was supposed to be a new regime for the world economy. ${ }^{33}$ These understandings were

\footnotetext{
29 Charnovitz calls particular attention to a group of bilateral and multilateral initiatives that produced embryonic international law norms and regimes, which later would evolve into the GATT or other international economic agencies. For instance, the 1890 International Union for the Publication of Customs Tariffs would become today's International Customs Tariff Bureau, while most-favoured-nation $(\mathrm{MFN})$ and national treatment standards established under peace, friendship and commerce treaties were widely used in drafting the GATT. He justifies the focus on international trade law on economics: [a] timeline for all of [IEL] would be too lengthy for a short essay, but it would be possible to construct a timeline underlying the construction of the world trading system in the late 1940s. He adds "[f]rom the scholarship that I am aware of, the trading system is a common element of everyone's concept of [IEL]" (Charnovitz, above n 22, at 611-612).

${ }^{30}$ Charnovitz, above n 22, at 611-614. See also Trebilcock et al, above n 28, at 23-24; Lowenfeld, above $\mathrm{n}$ 22, at 21-23; Winham, above n 28, at 9-13; Herdegen, above n 28, at 14-15; John H. Jackson, The Evolution of the World Trading System - The Legal and Institutional Context, in THE OXFORD HANDBOOK OF

INTERNATIONAL TRADE LAW 31-33 (Daniel Bethlehem ed., 2009).

31 Ibid.

32 The 1930 Smoot-Hawley Tariff Act was responsible for raising the United States's duties on imports to an average of 60 , its highest tariff rates in the $20^{\text {th }}$ century (Trebilcock et al, above $\mathrm{n} 28$, at 23).

33 Charnovitz, above n 22, at 614-616; Jackson (2007), above n 28, at 3-4; Jackson, above n 30, at 31-34; Lowenfeld, above n 22, at 21-26; Winham, above n 28, at 14; Trebilcock et al, above n 28, at 24-25; Herdegen, above n 28, at 195-197.
} 
used, during and after the Second World War, for choosing economic policies and designing legal norms and regimes to lay the foundations for a new international economic order. When it had become reasonably clear to the allies that World War II would be shortly over, the Anglo-American diplomacy paved the way for concluding the Bretton Woods Agreement in 1944. This agreement set forth a comprehensive plan to establish specialised international organisations for reconstructing and governing the global economy under the future United Nations. ${ }^{34}$ Following the end of the war, the International Monetary Fund and the International Bank for Reconstruction and Development (later the "World Bank") were duly created. However, the International Trade Organisation (ITO) failed to come into existence, largely because of the United States' refusal to ratify its Charter in 1947, arguing that its rules would impose excessive constraints on domestic economic sovereignty. 35

Alternatively, the General Agreement on Tariffs and Trade, an interim agreement, negotiated in 1947 as a prelude to the ITO, became, "through the magic of practice," the permanent institutional architecture for the multilateral trading system until the establishment of the World Trade Organisation in 1995. ${ }^{36}$ Between 1947 and 1994, the GATT not only evolved institutionally but also had its mandate and membership expanded. ${ }^{37}$ Under the GATT, eight multilateral rounds of trade negotiations were concluded. The first six rounds (from the 1947 Geneva Conference to the 1963-1967 Kennedy Round) focused almost exclusively on market access. The 1973-1979 Tokyo Round, although also promoted substantial tariff reductions, sought to negotiate for the first time new rules and policies, directing attention to various areas of non-tariff barriers to trade. The 1986-1994 Uruguay Round, the last and most complex negotiation under the GATT, entailed a profound transformation in the world trading system. The establishment of the WTO was one of its central achievements followed closely by

\footnotetext{
${ }^{34}$ More precisely, the Bretton Woods Agreement envisaged the creation of three new international economic organisations: IMF, World Bank and ITO. The IMF, responsible for governing global monetary policy through the maintenance of exchange rate stability, and the provision of assistance to countries facing balance of payment crises. The World Bank was in charge of international financial policies, which consisted initially of providing reconstruction to countries whose economies had been devastated by the Second Wold War. After having successfully contributed to the Marshall Plan, the mandate of the World Bank was expanded to focus on providing development capital to developing countries. The ITO was conceived to govern the negotiation and administration of a new international trading regime (Trebilcock et al, above n 28, at 24-25).

${ }^{35}$ Interestingly, the conventional literature often goes beyond the negotiations leading up to the draft ITO Charter. Notwithstanding, Charnovitz's institutional storyline stops at this historical landmark, leaving the impression that the events prior to the GATT rest on the past while placing the post-1947 institutions in the present. This understanding would make sense if Charnovitz's jurisprudential narrative followed the same timeline; however, as I shall discuss below, he does not. Instead, he tells the evolution of IEL jurisprudence from the interwar period until the early 1990s, and then to the present.

${ }^{36}$ Hélène Ruiz Fabri, Chapter 16 - Regulating trade, investment and money, in The Cambridge Companion to International Law 365-366 (James Crawford and Martti Koskenniemi, ed. 2012).

${ }^{37}$ Jackson, above n 28, at 4; Jackson, above n 30, at 34-37, 42-43; Lowenfeld, above n 22, at 46-67; Winham, above n 28, at 14-21; Trebilcock et al, above n 28, at 24-26; Herdegen, above n 28, at 15-16, 195-199.
} 
the reform of the dispute settlement mechanism and the unprecedented expansion of regulatory competence over trade in agriculture, textiles and services, intellectual property and investments. 38

Thus, the adoption of the WTO agreements in 1994 closes the final chapter of the institutional storyline. From ITO's tragic failure to GATT's defective birth and its incremental improvements throughout multilateral rounds until the acceptance of the WTO 'constitution', conventional history teaches that the contemporary world trading system is the product of a progressive evolution of institutional trade practices of sovereign states in pari pass $u$ with the continuous expansion of global economic interdependence.

\section{B. The Jurisprudential History of International Economic Law}

Juxtaposed with this institutional storyline, Charnovitz provides a historical account that identifies the IEL field with the progression of canonical writings. ${ }^{39}$ In section III, he retells the conventional narrative of the evolution of legal ideas and practices that led up to the formation of a vernacular of concepts and techniques employed by the 'champions' of IEL to make sense of international economic relations. The jurisprudential development is closely knitted to the continuous institutionalisation of international economic governance. 40

The jurisprudential story begins by acknowledging the German-American Ernst Feilchenfeld (1898-1956) as the patron of the term international economic law. ${ }^{41}$ Yet, Charnovitz asserts that "[i]f anyone should be recognised as the father of [IEL], it is the German-British Georg Schwarzenberger (1908-91), a professor of international law at the University of London, who began writing on [IEL] in 1942." 42 Schwarzenberger authored seminal works in IEL over three decades. In his classical 1966 course delivered at The Hague Academy of International Law, IEL is defined as a specialised province of public international law constituted of a sufficiently coherent, self-contained corpus of legal rules created by legal subjects, and not by deductions from abstract principles, with the purpose of regulating

\footnotetext{
38 Other important achievements were the following: the replacement of the 'GATT à la carte' approach for the 'single understanding' approach ensured that all members would be subject to the entire body of WTO agreements; and the creation of the Dispute Settlement Body represented the passage from a power-oriented to a rule-oriented system.

${ }^{39}$ Charnovitz, above n 22, at 616-624.

${ }^{40}$ In contrast to Section II however, section III focuses almost exclusively on the IEL jurisprudence developed from the 1940s until the 2010s, leaving aside canonical texts that were older or solely dedicated to international trade law. This far-reaching storyline differs not only from the institutional story but also from the conventional literature. Since Charnovitz does not explain these differences, I will follow the mainstream accounts, which means to limit the canonical narrative to 1994 , and complement it with international trade law.

${ }^{41}$ Ernst Feilchenfeld, firstly, coined the term in his 1938 book The Next Step. A Plain Man's Guide to International Principles (Charnovitz, above n 22, at 2014: 616-617. See also Ernst H. Feilchenfeld, THE NeXT SteP. A Plain Man's Guide to International Principles (1938), at 22-23).

${ }^{42}$ Charnovitz, above n 22, at 2014: 617.
} 
public-law aspects of international economic transactions. ${ }^{43}$ The term international trade law is not employed in this work. Rather, the regulation and institutionalisation of inter-state trade affairs are regarded under the realm of IEL.

Until the 1980s, Schwarzenberger was the leading, but not the only, scholar of IEL. The British Leslie C. Green (1920-2011) and David Hughes Parry (18931973) and the Hungarian-American Stephen A. Silard also employed the term IEL and advocated for the existence of a new branch of international law. ${ }^{44}$ Despite their scholarly efforts, Charnovitz points out that the concept international economic law was not "extensively used in international law literature during the 1950s, 1960s, or 1970s. But it does occasionally appear." 45

As a branch of international law, IEL only took off in the early 1980s. ${ }^{46}$ The Dutch Pieter VerLoren van Themaat (1916-2004) rediscovered the field in his treatise The Changing Structure of International Economic Law of 1981, whereby the Schwarzenberger's definition was reintroduced and updated in light of the new context. The term gained currency shortly after among the 1980s generation of international economic lawyers. ${ }^{47}$ Nevertheless, Charnovitz confers to the American John H. Jackson (1932-2015) the title of "the greatest champion of the concept of [IEL]" for his extensive contribution to the field.48 Jackson's seminal contribution was an entry on the term international economic law in the Encyclopaedia of Public International Law of 1985. This concept would be employed in his masterpiece of 1989, The World Trading System, whereby IEL is conceived not as a

\footnotetext{
43 "International Economic Law is concerned only with such aspects of economic phenomena as come within the purview of Public International Law. The reasons for this delimitation are not metaphysical. They are, partly, doctrinal and, partly, pragmatic" (Georg Schwarzenberger, The principles and standards of international economic, 117 RECUEIL DES COURS 7-8 (1966). See also, Georg Schwarzenberger, The Province and Standards of International Economic Law, 2 THE INTERNATIONAL LAW QUARTERLY 405-405 (1948); and Georg Schwarzenberger and E. D. Brown, A MANUAL of InTERnATIONAL LAW (1976).

${ }^{44}$ Charnovitz, above n 22, at 619. See also Leslie C. Green, Booke Review of International Arbitral Awards and International Tax Agreements, 1 Journal of the Society of Public Teachers of Law 322-324 (1949); David Hughes Parry, The Place of Constitutional Law and International Law in Legal Education, 2 JOURNAL OF LEgAL EDUCATION 428-432 (1950); Stephen A. Silard, The Impact of the International Monetary Fund on International Trade, 2 JOURNAL OF WORLD TRADE LAW 121-132 (1968).

${ }^{45}$ Charnovitz, above n 22, at 619.

$46 \mathrm{Ibid}$, at 620 .

47 VerLoren van Themaat was followed by the German Norbert Horn and Ernst-Ulrich Petersmann, the Austrian Ignaz Seidl-Hohenveldern (1918-2001), and the American John Jackson and Robert Hudec (1934-2003).

${ }^{48} \mathrm{Ibid}$, at 620. For the wide acknowledgement of John Jackson as the inventor of IEL, see generally Kennedy, above n 13, expanded in David Kennedy, The International Style in Postwar Law and Policy: John Jackson and the Field of International Economic Law, 10 AM. UNIV. INT'L L. REV. 671-716 (1995); Robert Howse, The House that Jackson Built: Restructuring the GATT System, 20 MiCHIGAN J. INT'L L. 107-119 (1999); Robert B. Thompson, John Jackson's Legacy: Defining a Field, 19 J. INT’L ECON. L.317-322 (2016); Tomer Broude, A Field of his Own: John Jackson and the Consolidation of International Economic Law as a Scholarly Domain, 19 J. INT'L ECON. L. 329-331 (2016); Gary Clyde Hufbauer, Wortby of a Nobel: An Appreciation of John H. Jackson, 19 Journal of International Economic Law 353-354 (2016). For the role of John Jackson in IEL practice, see generally Debra P. Steger, John H. Jackson-WTO Institution Builder, 19 Journal of International Economic Law 339-341 (2016); Gary Horlick, John Jackson as a Resource for Scholars and Others, 19 J. INT'L ECON. L. 401-402 (2016); William J. Davey, John Jackson and the Rule of Law, 19 J. INT'L ECON. L. 333-334 (2016).
} 
well-defined concept. Rather, a functional approach is offered to identifying IEL rules and institutions, while avoiding the rigid demarcations between financial, monetary and trade law, and between international and domestic law. ${ }^{49}$ In this sense, international trade law is purposefully demarcated as a branch of IEL, whereas the GATT/WTO law is defined as the centrally organised system of the most complex and extensive trade rules and institutions.

Charnovitz's jurisprudential history goes beyond John Jackson's scholarly contribution accounting also for his leading role in the field of international economic law. ${ }^{50}$ Coincidently or not, the year of 1994 was not only remarkable for IEL lawyers due to the conclusion of the WTO agreement, but also for the professional acclamation of Jackson as the creator of the field. ${ }^{51}$ This celebration symbolises the end of the jurisprudential journey. From the classic work of Schwarzenberger to Jackson's masterpiece, international economic law as a history of legal ideas and practices evolved from a formalist claim for normative autonomy to a functional approach to governing the world economy.

\section{Learning from the History of International Economic Law}

The history of the IEL field told by Charnovitz is neither novel nor controversial. Rather, it represents the conventional narratives that are widely accepted, complemented and repeated by the mainstream literature. To understand the role of history in international economic law and governance, two questions are central. The initial one asks as to what we - international lawyers have learned from these historical accounts. The above analysis suggests that the conventional narratives are constructed according to a characteristic style of legal history, which often combines an institutional story with a jurisprudential story. These accounts convey two central lessons aiming to organise the discipline's moral values, ideas and methods around a normative core, which sustains the

\footnotetext{
49 Charnovitz, above n 22, at 620; John H. Jackson, The World Trading System: LAw AND POLICY OF INTERNATIONAL ECONOMIC RELATIONS 25 (1997).

${ }^{50}$ Charnovitz explains (above n 22, at 621) that John Jackson, in his International Economic Law: Reflections on the "Boilerroom" of International Relations, argues that IEL "embra[ces] the law of government regulation of economic matters; and related legal relations including litigation and international institutions for economic relations. Indeed, it is plausible to suggest that ninety percent of international law work is in reality international economic law in some form or another" (John H. Jackson, International Economic Law: Reflections on the Boilerroom of International Relations, 10 AM. U. J. INT'L L. \& POL'Y 596 (1995)). Jackson also notes that [IEL] cannot be separated from public international law. In addition, he points to the value of a multidisciplinary approach to [IEL] which embraces not only economics, but also political science, cultural history, anthropology and geography (Ibid, at 598). Charnovitz goes further to show how the notion of IEL "becomes further solidified" by the contribution of other international lawyers and foundation of specialised law journals (above $\mathrm{n} 22$, at 621-622).

51 The 1994 Conference on Interdisciplinary Approaches organised by the American Society of International Law celebrated Jackson's work as fundamental to the consolidation of the field's intellectual and professional pillars. In the rest of section III, Charnovitz covers the contemporary developments, involving the solidification of IEL jurisprudence until 2011. In brief, this process encompassed the publication of three specialised journals and new books and treatises, and the creation of International Economic Law and Policy Blog in 2006 and the Society of International Economic Law in 2008 (Charnovitz, above n 22, at 621-624).
} 
imagination of IEL as an autonomous province. Ultimately, their aspiration is to provide legitimacy and authority to support the IEL field's identity, mission and influence in global economic governance.

The first central lesson is learned from the story about the progressive institutionalisation of the world economy. ${ }^{52}$ The turn-to-institutions in international economic relations teaches that the foundation of contemporary international economic law going from 1944 to 1994 was realised through two gradual stages. The initial stage was precursory, serving to set up the normative architecture underscoring global economic governance. ${ }^{53}$ IEL rules and institutions negotiated by states are perceived as mostly defective, weak or incomplete, while their application is regarded as highly dependent on economic preferences and material power of contracting-parties. This notion of imperfect institutionalisation is used to explain the prevalence of the diplomatic and technical character, rather than legal or juridical, of the post-war international economic regime.

That precarious situation began to change in the 1970s, when the IMF, then the World Bank, and finally the GATT and international investment agreements, had their normative and institutional features reformed and advanced. ${ }^{44}$ This second stage increased the institutionalisation of international trade, monetary and financial regimes, furthering the implementation of (Neo-)Liberal policies by constraining state discretion and incrementally moving their governance towards more rule-oriented international systems of economic cooperation. This shows that, while the 1940s is perceived as the constitutive moment in which countries committed to the contemporary international economic order, it was only in the 1980s that international law rules and institutions began to be used more extensively to govern inter-state economic relations. Therefore, this institutional story has been traditionally told not only as holding singular significance to today's global governance, but also as having a foundational role in constituting the contemporary IEL field. It teaches, particularly, that IEL results from the successful institutionalisation of the Neoliberal programme through the gradual transformation of the global economic regime from politics to diplomacy to law.

The second central lesson comes from the advancement in jurisprudence as a response to the post-war move to institutions. ${ }^{55}$ The conventional narratives chronicle that some lawyers discovered that international legal norms and regimes devised to regulate international economic relations possessed a special quality. This led them to differentiate this 'branch' of international law from other

\footnotetext{
${ }^{52}$ For the institutional story of international economic law, see generally above n 27-38, and accompanying text.

53 See generally above $\mathrm{n}$ 27-37, and accompanying text.

54 See above n 37-38, and accompanying text.

55 For the jurisprudential story of international economic law, see generally above $\mathrm{n}$ 39-51, and accompanying text.
} 
provinces. ${ }^{56}$ The 1940 s generation led by Schwarzenberger is perceived by the traditional literature as concerned primarily with formal and legalist dimensions of IEL. ${ }^{57}$ This formalist-oriented mind-set is regarded as responsible for letting lawyers enclose themselves in excessive academicism, while other fields of international economic policymaking occupied the central position in global governance.

Side-lined for three decades, IEL expertise is considered to have been reborn to global economic governance only in the 1980s thanks to the determination of more pragmatically-driven, rather than academically-oriented, international lawyers. They sought to rethink legal expertise as a way of reclaiming their participation in international economic policy- and law-making. ${ }^{58}$ The conventional accounts chronicle how lawyers gradually shifted from a formalist, legalist, positivist mind-set towards functionalist, realist and pragmatic attitudes and mentality.59 They were less interested in ontological and epistemological disputes over the existence of IEL, and more preoccupied with its functions, effectiveness, and the application of its expertise to solve problems of the world economy. By strategically linking considerations of validity and effectiveness, the 1980s generation led by Jackson significantly transformed the IEL field. ${ }^{60}$

\footnotetext{
${ }^{56}$ Chronicled as a 'eureka' moment, they later found out that this unique domain was, in fact, an autonomous field, and so named it as international economic law. Despite the efforts of those frontrunners, the emergence of the IEL expertise is conventionally regarded as having had little or no influence over international economic law or governance. Three factors are considered to have collaborated for its disempowerment. The political and economic challenges pervading the 1950s, 1960s and 1970s would have accrued a chilling effect on international lawyers' aspirations. Moreover, the postwar international economic order would have been operated and managed mostly by non-legal experts, to the extent that international economic affairs were considered of 'low' political priority and dominated by more 'technical', and less or none 'juridical', matters. Finally, the 1940 s generation led by Schwarzenberger was too scholarly inclined and committed to stronger legalist and positivist views of international economic law (See above n 41-51, and accompanying text. See also Kennedy, above n 13, at 61; Reich, above n 13, at 775-776; Weiler, above n 13, at 194-197; Howse, above n 13, at 98-99 (2002)). 57 They focused on the formal question as to whether IEL was ontologically and epistemologically distinct from international law. Consequently, legal theory occupied a prominent place in debates about IEL's nature, driving the choice of methods to identify formal concepts and legal sources. More specifically, IEL was conceptualised, examined and applied as if it were a coherent and self-contained system of distinguished positive rules and institutions (See above $\mathrm{n} 46-51$, and accompanying text). 58 See above n 22, 46-51, and accompanying text.

59 See Charnovitz, above n 22. See also Weiler, above n Error! Bookmark not defined., at 194-197; Howse, above n 48, at 107-119, and n Error! Bookmark not defined., at 98-99; Reich, above n Error!

Bookmark not defined., at 775-776; Hufbauer, above n 48, at 352-353; Broude, above n 48, at 329-331; Thompson, above n 48, at 317-320; Davey, above n 48, at 333-334.

${ }^{60}$ The 1980's generation led by Jackson is praised for having introduced the central transformations that revived the IEL field. First, they bracketed the controversies over the formal autonomy of IEL, and recast their different views not as mutually exclusive responses to theoretical questions, but rather as alternative realist methodologies that could be chosen and applied to solve IEL-related disputes and problems according to personal conviction and contextual necessity. Charnovitz's article depicts the move to functionalism in sections I and III. While section III accounts for the jurisprudential story, section I introduces the different 'concepts', 'methods' or 'approaches' to IEL. These legal ideas and techniques are presented not as ontological responses framed as true or false hypotheses provided by legal scholars in historically situated contexts. Rather, they are juxtaposed as ahistorical, neutral, scientific methodologies to be chosen by lawyers not due to their inherent validity or legitimacy but according to contextual considerations and personal belief (Charnovitz, above n 22, at 607-611, 616-624). Second, the
} 
These two central lessons provide the normative consensus underlying the contemporary field of IEL. By combining institutional and jurisprudential dimensions, the history of its constitution is regarded as having undergone through three steps: the 1940s as its formal, normative and intellectual roots, the 1950s-1970s period as its institutional maturation but professional marginalisation, and, finally, the 1980s-1994 as its effective foundation. Legal functionalism, realism and pragmatism are the building blocks of the field's identity, while its core mission is the progressive implementation of the Neoliberal programme for global economic governance through international law.

This leads to the second question: what is the function of history in the IEL expertise? It is common sense that history-telling is used by international lawyers as a mode of governance to control the movement of meanings across time. The traditional literature often offers narratives alike to manage and support a wide variety of projects, rules, institutions, theories and methods that constitute the IEL expertise. As analysed above, these accounts may take the form of institutional stories of the formation and development of IEL norms and regimes that nowadays underscore the international economic order. Likewise, they may contribute to the understanding and diffusion of current legal ideas and techniques by retelling the evolution of IEL jurisprudence. By connecting past and present, these history lessons organise and mould legal expertise, which in turn affects lawmaking and interpretation. Moreover, these teachings are continuously reasserted as a strategy to sustain the authority and legitimacy of the IEL field's identity and mission. This suggests that the way in which lawyers tell their own history plays an important role in shaping (directly) the boundaries of the IEL domain and influencing (indirectly) global economic governance.

\section{The Traditional Approach to the History of International ECONOMIC LAW}

The analyses of Howse's and Charnovitz's works suggest the operation of what I have called the traditional approach, a characteristic style of history-telling that widely dominates the field of international economic law. Charnovitz's article illustrates how institutional and jurisprudential stories are habitually organized and merged into a 'grand narrative' about the origins and development of IEL, while Howse's recollection exemplifies the way in which this instance of conventional

\footnotetext{
move from grand theories to functionalist methods of analysis was combined with an instrumentalist approach to IEL, through which the validity and legitimacy of a legal norm or regime were tested against its effectiveness in providing the legal basis for dealing with concrete cases of international economic affairs. The instrumentalist turn is clearly reflected in section IV, whereby Charnovitz does not analyse the relationship between IEL and international law from a formal or normative viewpoint. In contrast, he examines whether and how IEL should influence or interact with international law with the aim of solving current challenges faced by global governance (Charnovitz, above n 22, at 624-625). Finally, this pragmatic perspective shifted the focus of IEL expertise from legal certainty and stability to problemsolving, normative change and institutional progress.
} 
accounts is routinely translated into history lessons and then taught to international lawyers worldwide. Together they show how the traditional approach has been used to combine institutional and jurisprudential teachings with the purpose of drawing a line dividing whom and what are parts of IEL. Particularly, this dominant style of history-telling is employed to determine what/who matters or not to the field's past, and also to control what lessons should be taken into consideration today by lawyers to make or interpret IEL projects, rules, institutions and ideas.

Against this backdrop, I argue that the majority of international lawyers have successfully employed the conventional narratives to construct and sustain IEL as a professional and intellectual field. The traditional approach is continuously used as an expert mode of governing the legitimacy and authority of actors, ideas, rules and regimes. On the one hand, it is used to draw a temporal timeline dividing past and present for the IEL expertise. Legal norms, actors and knowledge that are not understood as being part of the 1980s (re-)foundational moment are mainly regarded as belonging to the past. Consequently, they do not or should not inform today's practices and ideas. On the other hand, it is employed to draw spatial lines, separating which elements fit in and out the IEL discipline. Legal rules, actors and knowledge closely related to the Neoliberal programme for global economic governance are often acknowledged as part of IEL, ${ }^{61}$ while the ones identified with environmental, social, labour and development issues tend to fall outside the field, regardless of their economic relevance. ${ }^{62}$ Similarly, theories, methods and arguments associated with legal functionalism, pragmatism and realism are habitually received without ideological suspicion or intellectual scepticism, whereas the ones grounded in competing schools of thought ${ }^{63}$ are frequently dismissed or marginalised.

Furthermore, the disciplinary consensus produced through the traditional approach around the IEL boundaries entails important external consequences. By using the conventional narratives to assert the present field's frontiers, international lawyers intend not only to claim exclusive authority over certain (and not other) institutional and jurisprudential domains but also to legitimise their pursuit of specific (and not other) projects for global economic governance. This, in turn, affects their interaction with other international economic policymaking experts as well as with international regimes for economic affairs. The purpose of using the traditional approach is, therefore, to empower international lawyers with legitimate authority to make sense of and arguments about official documents and behaviours of state and non-state actors (related to what they understood to be

\footnotetext{
${ }^{61}$ For instance, the IMF, the World Bank, the GATT/WTO and IIAs.

${ }^{62}$ For instance, the United Nations Conference on Trade and Development (UNCTAD), the United Nations Industrial Development Organisation (UNIDO), and the International Labour Organisation (ILO).

${ }^{63}$ For instance, legal positivism, natural law, Third-World Approaches to International Law, postcolonialism, post-structuralism, and feminist jurisprudence.
} 
part of international economic affairs) to politicians, diplomats, judges, other policymakers and scholars, students, and, very importantly, to themselves.

This suggests that the traditional approach to history-telling operates less as a means to reflect upon how past acts and choices led up to the present. Instead, it works backwardly by selecting and mobilising historical events to legitimise and validate the consensus around the linear connection between the IEL field's origins, development, autonomy and present-day boundaries. In this sense, lessons that are 'discovered' in history tend to reflect collective or individual commitments of lawyers to intellectual traditions, normative projects and professional groups. In particular, my analysis indicates that the majority of lawyers have continuously applied the traditional approach to entrench and sustain the Neoliberal programme into the IEL expertise by controlling the authority and legitimacy of actors, ideas and practices as well as norms and regimes through the conventional accounts of jurisprudential and institutional stories.

Therefore, I believe that the limitations of international lawyers in addressing the current challenges to the international economic order have a great deal to do with the ways in which historical narratives have been used to legitimise and validate norms, actors and knowledge. My aim is to explore what an analysis of the IEL field's history and boundaries can tell us today about the repertoire of ideas, practices, rules and institutions that was relegated to the dustbin of past due to disciplinary consensus. I am specifically interested in uncovering and criticising the strategies undertaken to entail demarcation effects so as to assist in broadening the horizons of possibility to propose alternatives to transform international economic law and governance.

\section{BETWEEN HISTORY AND BOUNDARIES: THE LIMITS OF THE TRADITIONAL APPROACH TO THE HISTORY OF INTERNATIONAL ECONOMIC LAW}

As the previous section suggests, boundary-drawing and history-telling tend to be assumed as unrelated, or perhaps contrasting, disciplinary modes of governance situated on opposite sides of the IEL expertise. By contrast, the traditional approach has in fact combined history and boundaries, in order to reconstruct (what I have called so far) conventional narratives. The purpose of these historical accounts has been to legitimise and validate the IEL field's borders by controlling the intra-expertise production of knowledge and norms, and to ensure its extraexpertise influence by carving out an exclusive space for policymaking in global economic governance. By instrumentalising history to drawing boundaries, the past is subordinated to the present in order to determine as to whether a project, norm or idea is either a present-day outcome of progressive development (and so belonging to the field), an old (and non-applicable) relic or a non-part of the IEL domain. I suggest, therefore, that one possibility to rethink the current constraints 
of the IEL expertise is through the understanding and critique of how the traditional approach has structured the interaction between history and boundaries.

There are numerous possibilities to approach the history of the IEL field rather than the traditional style. ${ }^{64}$ The conventional avenue of the $20^{\text {th }}$-century international law literature is - as explained by Marti Koskenniemi - to combine "accounts of the development of the States system with brief excursions into a well-defined circle of canonical texts." 65 This seems to capture how IEL has been historicised since the mainstream literature often combines stories of the institutional development of contracting-parties' practice with brief doctrinal analysis of official documents and canonical texts. ${ }^{66}$

As I shall discuss below, the traditional approach tends, consciously or otherwise, to instrumentalise IEL history in order to justify and legitimise a particular programme by claiming it is the natural or logical consequence of a neutral and universal set of lessons. Indeed, this traditional style often blurs the line drawn to differentiate historical reconstructions from normative projects. ${ }^{67}$ The peril of this approach consists of emphasising aspects of history that support one's underlying policy-ideological-intellectual commitment as factual determinants while leaving others necessarily (and perhaps strategically) in the forgotten realm of the past. As shown by the previous section, there are two types of storylines (which might be combined or not) that have been routinely employed to tell the history of the IEL field with the aim of demarcating its boundaries.

The institutional story chronicles the evolution of IEL as the progressive development of practices of states and international organisations pari pass $u$ with the continuous expansion of global economic interdependence. ${ }^{68}$ It tends to overemphasise political or economic forces as structural drivers, while downplaying the role of moral, social or legal norms, institutions and doctrines. ${ }^{69}$ Hence, this traditional style of history-telling is used to sustain lawyers'

\footnotetext{
64 For an overview of approaches to international law history, see generally Bardo Fassbender and Anne Peters (eds.), THE OXFORD HANDBOOK OF THE HistORY OF INTERNATIONAL LAW (2012); James Crawford and Martti Koskenniemi (eds.), The CAmbridge Companion tO InTERnATIOnAL LAw (2012). 65 Martti Koskenniemi, A History of International Law Histories, in THE OXFORD HANDBOOK OF THE History OF INTERNATIONAL LAW 960-961 (Bardo Fassbender and Anne Peters eds., 2012).

66 Section Error! Reference source not found. provides a brief analysis of the conventional history of international economic law. More specifically, I examined the ways in which Charnovitz accounts for the field's origins by merging a linear account of crises and institutional responses with a story of jurisprudential evolution moving from formalism to functionalism.

${ }^{67}$ Koskenniemi points out that "[t] he dominant voice [in writing about international law histories] has sounded a sociological register: 'Ubi societas, ibi ius'—although just what it means to say that the law 'reflects' anterior social developments has seldom been broached in any depth. Much of this history is geared in a policy-oriented direction as prologue to this or that agenda of reforms" (Ibid, at 961).

68 For a summary of the institutional story of international economic law narrated in traditional style, see generally above $\mathrm{n} 27-38$, and accompanying text.

${ }^{69}$ For an overview of a legal history approach to international law as institutional practice, see generally Gerry Simpson, Chapter 1 - International law in diplomatic history, in THE CAMBRIDGE COMPANION TO INTERNATIONAL LAW (James Crawford and Martti Koskenniemi eds., 2012).
} 
understanding of the GATT, IMF, World Bank and IIAs as servants, by-products of, or determined by, international economic relations.

The jurisprudential story accounts for IEL as the succession of canonical writings that provides a vernacular of concepts and techniques to understand the prevailing institutional interactions and state behaviour under global economic governance. ${ }^{70}$ The conventional narratives often overemphasise the evolution undergone by IEL jurisprudence from the 1940s mind-set characterised by a scholarly attitude and formalist-positivist views towards the 1980s mentality, which combined a pragmatic attitude and functionalist-realist visions. ${ }^{71}$ Thus, the traditional approach is employed to narrow the intellectual history to support lawyers' instrumental efforts to justify and legitimate the (re-)foundation of the IEL field, with the aim of closing the gap between legal expertise and the rival policymaking disciplines.

These two types of legal storylines are often united through the commitment of the traditional approach to a view of history as a single and universal phenomenon. Contemporary lawyers often try to merge the intellectual and institutional stories by assuming that both are somehow intertwined teleologically and progress linearly. ${ }^{72}$ The purpose of the mainstream literature in providing these two accounts following one common trajectory seems to be an attempt to scientifically capture the single, universal reason driving the IEL history. Indeed, this grand narrative is conventionally remembered as a conflict against autocracy, nationalism, discrimination, unilateralism, and protectionism, as well as against legal idealism, and excessive formalism, positivism and academicism. By contrast, an 'effective', 'legitimate' and 'fair' international economic law results from cooperation, multilateralism, non-discrimination, reciprocity, and liberalism, as well as legal pragmatism, functionalism, realism and problem-solving attitude. At the core, IEL is imaged as a universally accepted mode of institutionalised expert governance of the global economy that aspires to impose formal and effective constraints upon sovereign discretion over trade, monetary and financial policies, while promoting a more peaceful world and economic welfare through interdependence.

By resorting to the IEL history, the mainstream literature aims to validate and legitimise its normative project through the conventional narratives that vindicate the naturalness, necessity or superiority of contemporary IEL norms and knowledge. The traditional approach is employed to root the rules, ideas and techniques related to the WTO/GATT, IMF, World Bank and IIAs in history

\footnotetext{
${ }^{70}$ For an overview of a legal history approach to international law as legal ideas and practices, see generally Martti Koskenniemi, Chapter 2 - International law in the world of ideas, in THE CAMBRIDGE COMPANION TO InTERNATIONAL LAw (James Crawford and Martti Koskenniemi eds., 2012).

${ }^{71}$ For a summary of the jurisprudential story of international economic law in traditional style, see generally above n 39-51, and accompanying text.

${ }^{72}$ Martti Koskenniemi, Histories of International Law: Significance and Problems for A Critical View. 27 TEMPLE INTL. \& COMP. L.J. 220-221 (2013).
} 
lessons, so as to ascribe them meaning as part of an unfolding story of institutional and jurisprudential progress that serves to support the dominant, Neoliberal project. ${ }^{73}$ These historical reconstructions create, in turn, a disciplinary boundary by framing what is desirable in the IEL domain, while bracketing all other elements as 'outsiders'. ${ }^{74}$ The dangerous consequence of combining the institutional and jurisprudential stories through the lens of the traditional style is to produce a teleological view of the conventional accounts as the single, neutral and universal history of international economic law. The ultimate result is, therefore, to blur the line between past and present.

Recently, a new trend in literature has extensively criticised the traditional approach for its ontological and epistemological shortcomings. ${ }^{75}$ For the aim of my discussion here, the critiques of the mainstream literature's commitments to Modernism and Anglocentrism seem to bear great explanatory power. The combination of these two features appears to impose disciplinary limitations that have adversely impacted international economic law. These constraints result from the effects of the traditional approach over the interaction between the IEL history and boundaries. More specifically, it has produced a historical consensus around the IEL field's origins and evolution, which has, in turn, entailed the central lessons that demarcate what and who count or not as IEL.76 Intraexpertise, these teachings have been employed to shape not only projects, norms and knowledge but also the field's identity and mission. Extra-expertise, they have

\footnotetext{
${ }^{73}$ Orford makes a similar argument on how the dominant scholarship uses history to justify and legitimise free trade as the central project of contemporary international trade law and governance (Anne Orford, Theorizing Free Trade, in THE OXFord HANDBOOK OF THE THEORY OF INTERNATIONAL LAW 701702 (Anne Orford, Florian Hoffmann and Martin Clark eds., 2016)).

${ }^{74}$ For instance, it often tries to construct the history of international trade law by tying it up with the institutional story about the steps leading up to the formation and development of the GATT and the jurisprudential story about GATT's 'birth defect' that made legalist, positivist and formalist approaches unsuitable, and so demanded pragmatic, functionalist and realist methods. It ultimately instrumentalises these two 'history lessons' to develop theories, doctrines and arguments to solve contemporary issues on international trade law.

75 For this new strand in international law scholarship, see generally Martti Koskenniemi, above n 65 and 70, and his Law, Teleology and International Relations: An Essay in Counterdisciplinarity, 26 INTERNATIONAL Relations 3-34 (2012); Simpson, above n 69; Anghie, Antony, Imperialism, Sovereignty, and the MAKING OF InTERNATIONAL LAW (2005); Frédéric Mégret, Chapter 3 - International law as law, in THE CAmbridge Companion to International Law (James Crawford and Martti Koskenniemi eds., 2012); Emmanuelle Jouannet, THE LibERAL-WELFARIST LAW OF NATIONS: A History OF INTERNATIONAL LAW (2012). For international economic law, see specifically Lang, above n 2; Fabri, above n 36; Anne Orford, above $\mathrm{n} 73$, and her Food Security, Free Trade and the Battle for the State Work, 11 JournaL OF IntERnATIONAL LAW AND International RElations 1-67 (2015); James Thuo Gathii, African Regional Trade Agreements as Legal Regimes (2011); Sundhya Pahuja, Decolonising International Law: Development, Economic Growth and the Politics of Universality (2011); Donatella Alessandrini, The World Trade Organization and development Victory of 'rational choice'?, in Events: The Force of International Law (Johns, Fleur., Joyce, Richard John, and Pahuja, Sundhya (eds), 2011); Kate Miles, The Origins of InTERnATIONAL InVESTMENT LAW: EMPire, ENVIRONMENT AND the Safeguarding of Capital (2013); Luis Eslava, Local Space, Global Life: The Everyday OPERATION OF INTERNATIONAL LAW AND DEVELOPMENT (2015).

76 Howse and Charnovitz seem to experience the demarcation effects produced by the traditional approach, see above n 4-5, 13-17 (Howse) and n 52-Error! Bookmark not defined. (Charnovitz), and accompanying text.
} 
affected the authority and legitimacy of international lawyers over policy- and lawmaking domains of global economic governance.

The critique of Modernism starts off by calling attention to the argumentative structure embedded in the traditional approach. The preliminary step to historytelling is to define international economic law. ${ }^{77}$ This definition is habitually constructed upon two moves. It first assumes that lawyers are able to objectively isolate IEL from other social phenomena, such as morality, politics, and economics, as well as from domestic and international law, in order to provide a somehow definitive, abstract concept. Such a concept is often a specialised variation of the notion of IEL as a universal and neutral set of norms, regimes and doctrines that are legitimately produced and can be objectively interpreted. The second move is to accept that the positive rules and institutions underlying the IMF, World Bank, GATT/WTO and IIAs constitute the only, or the most relevant, body of international economic law.

These ontological and epistemological premises produce blind spots that often lead the traditional approach to overlook how intra-expertise political and intellectual struggles have shaped the contemporary IEL field. This implies that, to produce a universal history, conventional narratives frequently fail to take into consideration socio-economic contexts, political compromises or intellectual concessions responsible for making and interpreting IEL norms and regimes, while obscuring disciplinary bias and marginalising alternative ideas and practices within the IEL expertise. ${ }^{78}$ Therefore, embedded into the traditional approach, the Modernist commitment to teleology requires the adoption, preceded or not by theoretical justification, of a universal concept of international economic law as the condition sine qua non to begin the process of uncovering its history. This restricts, in turn, IEL history to the conventional narratives that often support the dominant programmes underpinning the concept chosen $e x$ ante.

My analysis of Charnovitz's article offers a good example of the perils arising from the Modernist style of IEL history. Two shortcomings are particularly important. First, the traditional literature narrows the notion of international economic law to the international laws of the GATT/WTO, IMF, World Bank and IIAs, accompanied or not by methodological reasons. The consequence is to impose a disciplinary demarcation that disregards any rule, institution or doctrine existing from 1944 to 1994 that falls outside such a narrow concept. Second, to reinforce this ontological and epistemological frame, the conventional narratives seem to function as an apologetic conduit providing legitimate and authoritative justifications for the prevalent body of contemporary IEL norms, regimes, practices and ideas.

\footnotetext{
77 See above n 5, 12-13 (Howse) and n 23-26, 60-Error! Bookmark not defined. (Charnovitz), and accompanying text.

78 David Kennedy, The Disciplines of International Law and Policy, 12 LEIDEN J. INT'L L. 12 (1999).
} 
The second critique is concerned with the overwhelming Anglocentrism surrounding and embedded into the conventional accounts. ${ }^{79}$ From physical places to intellectual debates to global policy-making, IEL is frequently experienced in the present-day mind-set and routines as an Anglo-American phenomenon. Locations such as Bretton Woods, New York, and Washington in the United States, London and Torquay in the United Kingdom are central to the historiography, where international lawyers have been constantly found, in some way, even today. Of course, other key places such as Geneva, Paris and Annecy, Brussels, Tokyo, as well as Havana, have also been historically important; however, the traditional approach seems to portray these places as islands, or perhaps containers, of Anglocentrism elsewhere. In fact, it seems discouragingly difficult and sometimes impossible to engage with international economic law without delving into Anglo-American diplomatic history, referring to ideas and practices about economic liberalism, multilateralism, and rule of law as imagined and implemented in the United States and the United Kingdom, or even communicating in the English language. This suggests the existence of an affinity between international lawyers' disciplinary preference and their acceptance of Anglocentrism. Thus, the IEL expertise is experienced as dominated by Anglocentric-inspired or -reconstructed norms, regimes and doctrines, as well as concepts and knowledge.

This Anglocentrism leads one to wonder what kind of IEL history would be possible without summarising it to the role of the US (mainly), the UK (secondarily) and Western Europe in the construction and maintenance of the international economic governance? Indeed, the overwhelming majority of the contemporary narratives, following either institutional or jurisprudential storylines, seem to drive back to what and how British and Americans have done and written. Institutionally, the literature tends to equate IEL to the IMF, World Bank, GATT/WTO and IIAs, by either foregrounding their ancestors in the 19thcentury, Liberal economic system led by Great Britain, or emphasising their origins in the Anglo-American negotiations that resulted in the Atlantic Charter. More specifically, it often retells the establishment of the international economic order through the debate between the American Cordell Hull and Harry Dexter White, and the British John M. Keynes. Jurisprudentially, it does not and should not come as a surprise that the mainstream literature unequally emphasises ideas and practices produced by Anglo-American (trained) lawyers. In the 1940s, the father of IEL, Georg Schwarzenberger, was a Jewish person born in Germany who found refuge in 1934 in the United Kingdom, where he came to develop his scholarship on the province of IEL as a professor at the University of London. In the 1980s, the great champion of IEL, John H. Jackson, was an American-born

\footnotetext{
${ }^{79}$ Likewise, Koskenniemi (above n 65 and 72), Anghie (above n 75) show how Eurocentrism shapes international law, while Orford (above n 73), Miles (above n 75) and Pahuja (above n 75) demonstrate the effects of Eurocentrism/Anglocentrism over international economic law.
} 
professor who, on different occasions, served the Office of the US Trade Representative. Therefore, the traditional approach seems to make it quite an impossible task to offer a credible account of international economic law and governance without adopting an Anglocentric viewpoint.

\section{TOWARDS AN ALTERNATIVE APPROACH TO THE HISTORY OF INTERNATIONAL ECONOMIC LAW}

In an attempt to address or avoid some of the shortcomings inherent to the traditional style of historicising international economic law, I provide below the contours of an alternative approach grounded in four strategies.

\section{WIDENING THE HISTORICAL BOUNDARIES OF INTERNATIONAL ECONOMIC LAW}

The first strategy purports to place the origins and development of international economic law within a broader historical trajectory. I propose to widen the scope so as to analyse the ways in which IEL was 'founded' in relation not only to the 'rest' of international law but also to the 'other' international economic policymaking domains and institutionalised regimes of economic governance existing between 1944 and 1994. This consists of retelling institutional and jurisprudential stories in light of a more comprehensive frame. Hence, the aim is to prevent the bias and blind spots created by traditional narratives from constraining today's IEL expertise in two important ways.

The acceptance of the idea of the GATT/WTO, the Bretton Woods institutions, the ICSID and IIAs as the unique, or perhaps ultimate, institutional and normative experiments of international economic governance since 1944, is a disciplinary pillar of the IEL field. This traditional perspective locks up IEL within dichotomous debates around utopian, Liberal, multilateralism versus apologetic, Welfarist, unilateralism. For instance, the history of international trade law looks very different from the conventional narratives if, instead of focusing only on the GATT and its internal conflicts, it accounts for the role of GATT in the battle against the UNCTAD and the COMECON for governing international trade affairs. ${ }^{80}$ Moreover, the jurisprudential consensus around the superiority of an

\footnotetext{
${ }^{80} \mathrm{My}$ argument is not that the mainstream literature has completely disregarded the existence of other international organisations or regimes specialising in economic affairs. Rather, I argue that it tends not to account for the other regimes as contenders for governing international economic relations. For instance, there were institutional alternatives to the GATT offered by competing expert projects and normative programmes that have been forgotten or ignored by the IEL history. From the 1950s until the early 1990s, global trade governance was organised around three multilateral trade regimes: the GATT, the United Nations Conference on Trade and Development and the Council for Mutual Economic Assistance (COMECON). For a general overview of the COMECON, see Endre Ustor, Decision-making in the Council for Mutual Economic Assistance, 134 RECUEIL DES COURS 163-295 (1971); Giuseppe Schiavone, The Institutions of Comecon (1981); Jozef M. Van Brabant, The Planned Economies And
} 
Anglo-American style of legal pragmatism, functionalism and realism developed since the 1980s singles out an innovative body of legal knowledge and practices produced since the 1940s. ${ }^{81}$ Not only has the traditional history led the IEL expertise to relegate a rich repertoire of legal ideas and techniques to the dustbin of the past, but it has also crystallised a disciplinary boundary that prevents recent preoccupations, concepts, theories and methods from growing or entering the field. ${ }^{82}$ For instance, it has marginalised relevant questions related to social justice and economic redistribution by justifying historically that development policies, environmental and labour concerns, and humans rights considerations fall outside the IEL domain. Therefore, a new approach to history purports to provide the ways to resituate the IEL expertise in a wider context of global economic governance.

\section{Endogenising the History AND BOUndaries OF INTERNATIONAL ECONOMIC LAW}

I suggest that we suspend our habit of imagining IEL as a special body of legal rules and institutions, which can be empirically identified and scientifically analysed. In other words, IEL can be conceived not as a result of a unilateral process of normative, jurisprudential or institutional specialisation or fragmentation, which is possible to be 'discovered' and 'apprehended' by international lawyers, regardless their historical context, through the identification of a distinguishable group of universal norms and regimes holding a natural or logical speciality.

Instead, I propose to approach the foundation and evolution of international economic law as (part of) the creation and advancement of the IEL field, which

INTERNATIONAL ECONOMIC ORGANIZATIONS (1990). For a general overview of the UNCTAD, see Said El-Naggar, The United Nations Conference on Trade and Development: background, aims and policies, 128 RECUEIL DES COURS 241-345 (1969); Mohamed Bennouna, Droit INTERNATIONAL DU DÉvELOPPEMENT: TIERS MONDE ET INTERPELLATION DU DROIT INTERNATIONAL (1983); John Toye, UNCTAD AT 50: A SHORT HISTORY (2014)

81 Today's mainstream jurisprudence of international economic law has often neglected the development of ideas, methods and doctrines undertook by international lawyers located outside the Anglo-American world. While American and British lawyers would only reengage with IEL in the 1980s, jurisprudential debates on IEL matters were intensively carried out in other places, such as Algeria, Egypt, France, and Nigeria. For a general overview of IEL in these legal traditions, see Mohamed Bedjaoui, TOWARDS A NEW INTERNATIONAL ECONOMIC ORDER (1979) and Madjid Benchikh, Droit InTERNATIONAL DU SOUSDÉVELOPPEMENT: NOUVEL ORDRE DANS LA DÉPENDANCE (1983) [Algeria]; El-Naggar, above n 80, and Georges Abi-Saab, Progressive development of the principles and norms of international law relating to the new international economic order (United Nations General Assembly, Report of the Secretary-Genera A/39/504/Add.1, 23 October 1984) [Egypt]; Nguyen Quoc Dinh., Patrick Daillier, and Alain Pellet, Droit International Public (1975) and Dominique Carreau, Thiébaut Flory and Patrick Juillard, Droit InTERNATIONAL ECONOMIQUE (1978) [France]; U. Oji Umozurike, InTERNATIONAL LAW AND Colonialism in Africa (1979) and Taslim Elias, New Horizons in InTERnATIONAL LAw (1992) [Nigeria].

82 Howse makes a similar claim when pointing out that the contemporary international lawyers have failed in rethinking IEL jurisprudence because they have been either unable or disinterested in taking seriously the new progressive scholarship in international economics (above $\mathrm{n} 3$, at 188). 
were carried out by a contextualised group of legal practitioners and intellectuals between the late 1940s and the early 1990s. ${ }^{83}$ Three consequences derive from understanding that the 'origins' and 'progress' of IEL were intertwined with the 'invention', 'maturation', and 'defence' of the IEL expertise. First, the IEL field is regarded as not only a formal body of rules, institutions, and doctrines, but also a way of thinking and practicing those norms, regimes or techniques. It involves the production, transmission and maintenance of knowledge between lawyers so that ideas and methods are routinely embedded ceasing to be politically or intellectually contested. In particular, the mainstream understanding of the IEL field's history and boundaries reflect emblematically the continuous labour of contemporary lawyers to encapsulate a specific set of political decisions, intellectual commitments, historical facts and normative positions into the conventional narratives.

Moreover, those historical accounts are regarded as carrying out central lessons that smooth the process of decision-making and consensus-building within the IEL expertise. These teachings are employed to 'construct' the IEL field having more or less influence depending on contingent factors related to the authority and legitimacy of their proponents and reasoning. In this sense, jurisprudential and institutional stories were neither neutral nor apolitical. Rather, they were produced by lawyers pursuing personal or collective projects, who are located in different jurisdictions, educated according to distinct legal traditions, and committed to divergent political groups and ideological mind-sets. ${ }^{84}$ The consequence of this view is to contest the field's traditional claim to universalism and perpetuity of IEL, since it cannot be sustained empirically, but only aspired to intellectually.

Thus, I suggest that the making of IEL history should combine an analysis of the field's intellectual history with an investigation of the performance of its members as designers, managers and interpreters of international economic law and governance. The purpose of an alternative approach is to investigate how inside disciplinary struggles and outside political-economic conflicts shape the

\footnotetext{
83 This approach to international law was inspired by the work of David Kennedy, Challenging Expert Rule: The Politics of Global Governance, 27 SYDNEY J. OF INT'L L. 3-12 (2005); David Kennedy, A WORLD OF Struggle: How Power, Law, and Expertise Shape Global Political Economy (2016); Andrew Lang and Joanne Scott, The Hidden World of WTO Governance, 20 Eur. J. INT. LAW 575-614 (2009); Martti Koskenniemi, Between Commitment and Cynicism: Outline for a Theory of International Law as Practice, in THE POLitics of international LAw (2011); Anthea Roberts, Is InTERNATIONAL Law InTERNATiOnAL? (2017).

${ }^{84}$ To understand international economic law as a transnational field, it is imperative to be aware of two basic sorts of internal dynamics: the intellectual dynamic of commitment and aversion and the professional dynamic of affiliation and disaffiliation. The interplay of intellectual and political disputes tends to determine relations of differentiation, dominance and disruption both inside and outside the IEL field. More precisely, the IEL boundary expands and diminishes by the continuous process of decisionmaking and consensus-building that underlies those group dynamics (Kennedy, above n 14, at 408-414; Roberts, above n 83 , at 1-6).
} 
construction, contestation and validation of historical narratives that constitute the contemporary understanding of the IEL field. ${ }^{85}$

\section{BREAKing up With MODERnism: IEL History as Temporal CONTESTATIONS OF DISCIPLINARY BOUNDARIES}

My proposal is to depart from the Modernist commitment to a progressive, linear and universal style of IEL history that often instrumentalises institutional or jurisprudential stories to reassert disciplinary boundaries so as to support particular programmes. ${ }^{86}$ This means to resist our impulse born out of the traditional approach to constructing narratives of IEL rules, institutions and doctrines by working backwards in order to 'uncover' a single lineage that justifies the natural or logical teleology we want to see hidden in history. To do so, I suggest recalibrating three main elements of IEL history-telling: frame, scope and scale.

Following the shift from positive norms to differentiated expertise, the focus should not be on retelling how legal rules, regimes, ideas and techniques have continuously and progressively evolved over time into their contemporary manifestations. Rather, the aim is to foreground the ways in which legal norms and knowledge are produced by contextualised groups of lawyers who pursue their projects through practice. This does not mean imposing a dogmatic separation between past and present aiming to completely sterilise the IEL history from critical engagements. I suggest emphasising, instead of erasing, intellectual conflicts and political battles that historically produced compromises, ruptures or transformations within the normative, institutional, doctrinal dimensions of IEL. Therefore, a new approach enables us to better understand the means by which the field's boundaries have constrained legal imagination by continually retelling the conventional narratives. In doing so, it would not only highlight the conditions of possibility that frame legal decision-making about and under IEL, but also

85 The IEL field is shaped by internal and external disputes over authority and resources. Within the discipline, there is the often-neglected interplay between domestic, national and transnational interactions among legal practitioners and academics. Lawyers pledges their allegiance to intellectual traditions, political groupings and normative programmes that are created and developed in contextualised settings. This implies that IEL ideas and practices are, in general, not universal or transnational per se, but rather nurtured in a particular place and then transferred to others. The importing-exporting dynamics can be seen as a form of 'transnationalised localism', which consists of a process by which a particular normative programme, jurisprudential project, or institutional vision succeeds in extending its reach over the IEL field and, by doing so, develops the capacity to designate a rival alternative as local. Not surprisingly, the acceptance and rejection of IEL projects, knowledge and techniques are deeply dependent on the relative geopolitical power of their production sites. As I discuss in this paper, theories, methods and doctrines developed in the United States have exerted far greater influence over the IEL expertise than the ones produced in France or African countries (Roberts, above n 83, at 8-9. See also Boaventura de Sousa Santos, Toward a New Legal Common Sense: Law, Globalization, and Emancipation 178-179 (2002)).

86 This strategy was inspired by Koskenniemi's approach to history of international law (above n 65 and $72)$. 
empower a critical engagement with international lawyers' past and present expertise and choices.

\section{Departing from Anglocentrism: IEL History as Spatial Contestation OF DISCIPLINARY BOUNDARIES}

This strategy consists of breaking up with Anglocentrism. ${ }^{87}$ If IEL is understood as a transnational field that aggregates lawyers from and working in multiple jurisdictions, historical narratives shall also be conceived as produced in sites located outside the Anglo-American world. This move entails two consequences. It is necessary to take into consideration that IEL has been thought and practiced in distinct contexts. Nonetheless, the validity and legitimacy of ideas and techniques hinge on the dynamic interplay between different legal communities within the IEL expertise. This disciplinary interaction is affected by the unequal distribution of authority and resources. Consequently, it is particularly important to be aware of the effects of certain 'spatial' differences over the production of approaches to legal history, as well as of the extent to which some of these styles of history-telling have come to dominate understandings of what counts or not as IEL in a way that can make them appear, or be presented as, neutral and universal.

Against this backdrop, I propose to move away from the traditional approach. Instead of equating IEL history with Anglo-American diplomatic and jurisprudential stories, the aim is to foreground the variety of historical narratives chronicled according to different approaches, each produced by the interplay of contextualised groups of international lawyers (within and across jurisdictions) facing political and intellectual communalities, dissimilarities and conflicts. Thus, I suggest that the interaction between the IEL history and boundaries would be different if lessons produced by lawyers situated in distinct states and regions and often associated with different communities were to be accepted as part of the IEL expertise rather than obfuscated by Anglocentrism. For instance, the European Paris, Brussels, Geneva, Moscow and Belgrade, the Mediterranean Algiers, Tunis, Rabat, and Cairo, the African Yaoundé, Lomé and Lagos, the Latin American Montevideo and Georgetown have been among the most relevant places where historical narratives have been constructed not only to shape the IEL expertise, but also to justify and legitimise ideas and practices to be used in making or interpreting legal norms, regimes and doctrines underlying global economic governance.

\footnotetext{
87 This strategy draws from the work of Koskenniemi (above n 65 and 72) and Orford (above n 73), who have historicised the ways in which Eurocentrism and Anglocentrism have shaped international law and international trade law, respectively.
} 


\section{Towards an Alternative Approach to the History of International ECONOMIC LAW}

All in all, my alternative approach to IEL history has three aspirations. It first intends to offer a way to rethink IEL history as a window to unveil how different groups of lawyers have participated in the foundation and development of international economic law. It aims to assist us in understanding how jurisprudential and institutional stories have been produced to govern the constitution, management and demarcation of the IEL expertise. In particular, it shall highlight the means in which these historical accounts have connected a 'certain' past to a 'certain' present in order to establish and sustain relations of difference, dominance and disruption inside and outside the IEL domain. Thus, this new style of history-telling purports to reveal how lessons have been extensively employed to draw the field's boundaries in ways that have affected international lawyers' understanding of and engagement with IEL.

The second goal is to help lawyers to understand the ways in which IEL has been employed to control the formation, management and contestation of normative, institutional and jurisprudential projects operating within the international economic order. For instance, it aims to foreground the continuous involvement of lawyers in the entrenchment of (Liberal-welfarist ${ }^{88}$, Socialist ${ }^{89}$, Developmentalist ${ }^{90}$ and Neoliberal $\left.^{91}\right)$ programmes into international economic

\footnotetext{
88 The so-called Liberal-welfarism is understood here to be the Anglo-American programme for a postwar international regime for economic cooperation aimed at striking a compromise between the aspiration for a multilateral system for trade, finance and monetary cooperation, on the one hand, and the call for national intervention on economic and social spaces, on the other (John G. Ruggie, International Regimes, Transactions, and Change: Embedded Liberalism and the Post-war Economic Order, 36 INTERNATIONAL ORGANIZATION 393-398 (1982); Jouannet, above n 75, at 249-253).

89 The so-called Socialism is defined here as a normative programme created and developed by Socialist countries in the context of the COMECON. It reflected a balanced compromise between the comradely aspiration for a multilateral regime devised to achieve formal and substantive equality among states through the implementation of "the international socialist division of labour in the interest of building socialism and communism in their countries," on the one hand; and, the voluntary desire to protect national sovereignty as the means for avoiding foreign interference in the state control of centrally planned domestic economies, on the other hand (Ustor, above n 80, at 183-1845, 275; Schiavone, above n 80 , at 3-8).

90 The so-called Developmentalism is conceived here as the Third-World programme led by the UNCTAD for an international regime for economic cooperation between developed and developing countries. The aim was at striking a compromise between two goals: on the one hand, the request for establishing a multilateral system for fairer, though dependent, economic cooperation; and, on the other hand, the desire for emancipatory intervention to foster economic development. This compromise between economic preference at international level and development interventionism at domestic level is at the core of the Developmentalist programme (Bedjaoui, above n 81, at 188-189, 250-253; Abi-Saab, above $n$ 81, at 102-104; Elias, above n 81, at 39-40, 208-209).

91 The so-called Neoliberalism is understood here as a normative programme developed as a reaction to the economic turmoil of the 1970 s, which contributed to erode the political and intellectual support for the Liberal-welfarism. It differs from the previous programme for several reasons, but two are central. First, it shifts the Liberal-welfarist compromise towards economic liberalism on both international and domestic levels. Second, it reimagines the world economy as a global market whose production and welfare potential are to be realised through 'deep' liberalisation (Lang, above n 75, at Part II; Orford, above $\mathrm{n} 73$, at 709-710; Howse, above $\mathrm{n} 17$ ).
} 
law. In particular, the purpose is to unveil how legal and non-legal experts collaborate to embody those projects into legal rules, institutions and doctrines, through ritualised processes of law-making and interpretation. With this in mind, a new approach aspires to historicise how legal ideas and techniques have been reworked through continuous practice in order to create and sustain normative, institutional and jurisprudential programmes, which have in turn provided the underlying vocabulary and the boundaries around what today we call the IEL field.

The third aspiration is to contribute to debates on contemporary issues of international economic law by rethinking the history of the present. Understanding IEL history as part of today's practice involves revealing how the work of embedding programmes through historical narratives has shaped the field's identity, mission and influence in global economic governance. Nowadays, it is common-sense to argue that IEL is somehow losing its effectiveness or perhaps heading towards a critical moment. The reasons lie partially in doubts about the limits of the Neoliberal project itself, and partially in fears about the capacity of IEL, as expertise and mode of governance, to provide solutions to present-day problems. In providing a new way of understanding the interaction between history and boundaries, an alternative approach aims at penetrating into the field so as to illuminate how it has constituted and moulded the conditions of possibility that enable and constrain lawyers to conceive and practice IEL in their engagement with the contemporary challenges to global economic governance. ${ }^{92}$

\section{CONCLUSION}

I opened this article by suggesting that the interaction between history and boundary is key to understanding the participation of international lawyers in the construction, operation and contestation of international regimes for regulating trade, monetary and financial affairs. Throughout the article, I have demonstrated that the IEL boundaries result from the interplay between intellectual debates meaningfully grounded in history lessons and the political disputes arising out of collective and individual pursuits of authority and legitimacy. In this context, the function of the traditional style of history-telling is two-fold. It narrates the past as teachings to support normative, jurisprudential and institutional projects for governing the world economy. It chronicles the past as lessons to conceive, frame,

\footnotetext{
92 Howse makes a similar argument when pointing out that the contemporary international lawyers have failed in rethinking IEL jurisprudence because they have been either unable or disinterested in taking seriously the new progressive scholarship in international economics led by Thomas Piketty, Dani Rodrik, Joseph Stiglitz and Jeffrey Sachs (above n 3, at 188). However, Howse might not have gone far or deep enough, to the extent that his "allies" are all economists situated at leading universities in the AngloAmerican world. There are also other non-legal experts whose cutting-edge work has been continuously overlooked or marginalised by the IEL field, such as Luiz Carlos Bresser-Pereira, Ha-Joon Chang, Mushtaq Khan, and John Ravenhill.
} 
argue and solve international economic problems through law. This means that the traditional approach has great responsibility for producing the conditions of possibility that empower and constrain lawyers' imaginative interaction with global economic governance. More specifically, I claim that this approach has excessively limited the IEL imagination preventing legal thinkers and practitioners from offering inventive solutions to dealing with the contemporary issues.

Furthermore, the upheavals within the Western developed countries (mainly caused by the Trump Administration and the Brexit negotiations) and the rise of China are reshaping international economic law and governance. It is reasonable to assume that these challenges will not vanish by themselves or wait for the IEL expertise to move beyond the consensus around the traditional approach. It is also expected that, if lawyers fail in participating in the construction of innovative proposals or alternatives, other experts and policymakers will fill in the gap. The consequence of inadequate or unsatisfactory engagement might cause the marginalisation of the IEL expertise within the global economic governance and the disruption of its core features.

If my analysis is correct, the IEL field should seek to relax its disciplinary frontiers in order to produce alternative ways to reform and transform the international economic order. This would include welcoming innovative projects, new ideas and inventive techniques from legal and non-legal experts located outside Anglo-American, orthodox sites. In addition, the IEL expertise should rethink its own history in order to recover the sense it once had that the field was characterised by normative heterogeneity, institutional experimentalism and jurisprudential innovation. I hope that the proposed alternative approach will assist in broadening the IEL boundaries so as to lessen the disciplinary constraints while empowering lawyers to re-imagine IEL in response to the contemporary challenges. Therefore, I want to conclude by offering some research avenues through which this new approach can expand our comprehension of history and boundary interaction.

First, I have suggested that the IEL field is critical in shaping the role of international economic law and lawyers in global economic governance. It is directly implicated in the ways legal practitioners and thinkers cope with the contemporary issues. Indeed, its influence is chiefly experienced through the control over the production and transmission of understandings, meanings, and knowledge related to the world economy. Boundary-drawing and history-telling function as modes of expert governance, constituted by political and intellectual dynamics, that determine the authority and legitimacy of who and what matter or not for IEL. In doing so, the IEL expertise structures the means and governs the range of choices that can be made as to whether certain norms, actors, ideas and projects are (part of) IEL. Studying the IEL field as practices of disciplinary differentiation, domination and disruption is thus studying the conditions of possibility sustained by the IEL expertise for lawyers to engage in new or alternative ways to reform and transform global economic law and governance. 
Through the analyses of the scholarly work of Robert Howse and Steve Charnovitz, I demonstrated that the pervasive use of the traditional style serves to instrumentalise history in support of boundaries. The link between the conventional narratives and the field's mission and identity is constructed and justified through views of the world economy's telos. This approach enables legal reasoning to work backwards in order to 'discover' history lessons accounting for a single lineage that validates and legitimises the natural or logical teleology embedded into legal norms, regimes and doctrines governing international economic relations. More concretely, past events are often selected and articulated by international lawyers, according to the Neoliberal programme, into storylines that provide institutional and jurisprudential teachings. Thus, a promising research avenue is to foreground the role of the traditional approach in the construction of lessons for evidencing the universal connection between the origins, development, purpose, content, and form of international economic law rules and institutions. In doing so, it opens the possibility of shedding light to a critical but oftenneglected function of the traditional approach, the use of history by (or as) disciplinary demarcation between IEL and 'the others'. The definition of the others relies upon the spatial and temporal dedifferentiation carried out by the IEL expertise. This includes drawing a line between IEL and other branches of international law and other expert domains of international economic policymaking, as well as between norms, regimes, ideas and methods that are part of the present or the past of IEL.

Grounded in a new trend in international law literature, I have criticised the traditional approach to IEL history for its ontological and epistemological limitations. I have suggested that the Modernism and Anglocentrism embedded in the traditional style appear to constrain rather than empower international lawyers to rework the IEL expertise in order to provide new and alternative responses to the current issues. In particular, these disciplinary commitments seem to have adversely impacted the IEL domain in two ways. At the intellectual level, they have narrowed the broad understanding the field once had of its origins and development. The consequence is that history lessons have been produced to vindicate the naturalness, necessity or superiority of a specific set of legal norms, regimes, ideas and techniques. At the professional level, those commitments have shaped the field's core elements, narrowing what and who do or do not count as (part of) international economic law. Therefore, the third line of scholarly inquiry is to unveil the constraining and empowering effects produced by the traditional approach over the IEL field through the teleological construction and maintenance of disciplinary boundaries.

In an attempt to address or avoid some of those shortcomings inherent to the traditional approach, the fourth strategy is to resituate the foundation and development of international economic law within a wider temporal trajectory and special context. The aim is to cause history-telling to take into consideration not only the 'rest' of international law but also the 'other' international economic 
policymaking domains and institutionalised regimes of economic governance existing between 1944 and 1994. More specifically, history lessons should be learned not as the outcome of a unilateral process of normative or institutional specialisation or fragmentation, which is possible to be 'discovered'. Instead, they should be conceived as part of the inside disciplinary struggles and outside political-economic conflicts underscoring the 'invention', 'maturation', and 'defence' of the IEL field itself.

Furthermore, I propose to retell the IEL history as single, universal, and neutral accounts of past events, but rather as contingent and partial stories carrying out normative programmes, institutional visions and jurisprudential projects. The alternative style of history-telling has the potential to uncover the moral and material roots of Modernism and Anglocentrism that are entrenched in the mainstream literature. Morally, the Anglo-American view of international economic law as an instrument for realising a specific (initially, Liberal-welfarist and, now, Neoliberalist) agenda has been tied up with the Modernist idea of universal and linear evolution. The result has been the development of institutional and jurisprudential stories to legitimise the field's contemporary identity and mission, by demonstrating that its origins and development go back to past events that are central for Neoliberalism and Anglo-American diplomacy. Materially, the dominance of Modernism and Anglocentrism has a great deal to do with the political and economic power of the United States and the United Kingdom in shaping international economic law and governance since the postwar period, but, especially, after the Cold War. Hence, this research avenue aims to use the alternative approach to provide a better map of the conditions of possibility that frame legal decision-making about and under IEL, and so critically engage in a dialogue with lawyers' past and present expertise and choices. 